\title{
E-Assessment for Characters Independence
}

\author{
https://doi.org/10.3991/ijim.v14i15.12995 \\ Asrial, Syahrial ${ }^{(凶)}$, Maison, Muhaimin, Dwi Agus Kurniawan \\ Universitas Jambi, Jambi, Indonesia. \\ Syahrial.karea@gmail.com
}

\begin{abstract}
This study aims to develop and implement an electronic assessment to evaluate the character of student learning independence. The implementation of e-assessment in this study is to see the character of student learning independence in science subjects and how the teacher responds to the development of e-assessment and evaluation of student learning independence with the MySQL system. This research method uses three stages, namely: (1) Development, (2) Implementation, and (3) Evaluation carried out on respondents totaling 529 students and 14 teachers in Jambi Province of Indonesia. The results of this study are validators stating that e-assessment to assess the character of student learning independence is in a very feasible category, and a valid statement is obtained from 24 statements with a reliability value of 0.870 . The results of this study indicate the character of students' learning independence is classified as good, with a percentage of $65.8 \%$ (348 students out of 529 students). The teacher's response is classified as good, with a percentage of $57 \%$ (8 teachers out of 14 teachers). So it was concluded that the E-Assessment received a good response and needed to be developed on a large scale.
\end{abstract}

Keywords-MySQL; Independence Characters; E-Assessment.

\section{Introduction}

In learning, attitude is an important aspect that should be taken into account [1], and the process of developing a student attitude is essential [2]; [3]. Students who have a negative view will have different attitudes with students who have a positive outlook during the learning process [4]. The 21st-century education requires humans to have the ability to use technology because the 4.0 industrial revolution influences it. According to the Law of the Republic of Indonesia Number 20 of 2003 concerning the national education system article 1, education is a conscious and planned effort to create the environment and learning process so that students will actively develop their potential to have the religious spiritual strength, the self-control, the personality, the intelligence, the noble morals, as well as the skills required of himself, society, and nation [5]. 21st Century learning has a basic principle that learning must be student-centered, collaborative, contextual, and integrated with the community. The role of the teacher in carrying out 21 st-century learning is very important in realizing a better future for the people [6]. Assessment and Teaching of 21st Century Skills (ATC21S) categorize 21st-century skills into four categories, namely ways of think- 
ing, ways of working, tools for working, and skills for living in the world. Education in the 21 st century is marked by the rapid development of information technology and the development of automation where many jobs that are routine and repetitive work are being replaced by machines, both production machines, and computers [7]. As we move into the 21 st century, these factors and many others are bringing strong forces to bear on the adoption of ICTs in education and contemporary trends suggest we will soon see large scale changes in the way education is planned and delivered as a consequence of the opportunities and affordances of ICT [8]. The learning process carried out can either be direct learning or learning through the help of information and communication technology.

E-Learning is learning using information technology facilities and communication. E-learning has been defined by the Joint Information Systems Committee (JISC) as learning facilitated and supported using information and communications technology [9]. For this paper, the following operational definition of e-learning will be used: the process of a training activity being conducted in an online environment [10]. The operational definition of e-learning, according to [10], is the process of training activities carried out in an online environment. Best practices of e-learning include features for collaborative learning, sharing, eliciting preferences, and an understanding of learning goals. Also, best practices include techniques that help reduce stress, fatigue, and errors related to the use of e-learning. Furthermore, innovation and creative use are carrying e-learning beyond the poor integration of technology into learning or the teaching and learning of computers [11].

Learning facilitated by electronic technology, or known as e-learning, includes a number of activities that may or may not involve network-based or web-based digital technology. Learning that is facilitated by electronic technologies, otherwise known as e-learning, encompasses several activities that may or may not include the use of networked or web-based digital technologies. E-Learning may be a web-assisted, or classroom learning that is facilitated by the use of a course website and the World Wide Web, or the mixture of classroom and online instruction known as the hybrid or adjunct model, or a fully online experience where all instruction and assessment occurs electronically [12]. Advantages in e-learning include the internet providing a number of facilities, the latest library resources, and the ease of access (anytime, by anyone, and everywhere) that is not limited by space and time [13].

Learning facilitated by information and communication technology cannot be separated from the educational assessment. The Education Assessment standard is a criterion regarding mechanisms, procedures, and instruments for evaluating student learning outcomes. The standard of assessment by educators, according to BSNP includes general standards, planning standards, implementation standards, processing standards, and reporting of assessment results as well as standards for utilizing assessment results [14]. [15] states that the form of education assessment can be either a test (objective, description, oral, appearance) or in the form of non-test (assignments, reports, interviews, portfolios, personal communication, and PBM implementation). Assessment is not a physical place as the name suggests, but it is an exercise designed to replicate real-life and requires participants to be involved in simulations [12]. 
Assessment is one of the main activities in the world of school education, starting from the level of basic education to higher education. In general and in the context of school education, assessment is an activity of gathering information about students or about program activities related to certain dimensions or attributes, such as student learning outcomes in teaching a field of study organized by the teacher, then compared with certain criteria to be concluded the quality of dimensions or attributes related to students or the program of activities concerned [16]. Assessments can be carried out for a variety of reasons and intentions that give the practice a particular perspective [17]. Assessment of learning outcomes in science is considered complete if it covers cognitive, affective, and psychomotor aspects [18]. So, an assessment can be done in electronic form which is often referred to as e-assessment. [19] said students are content with the new possibilities that the e-assessment based learning technology offer for teaching and learning, and no one advocates a return to a conventional unautomated approach. But technology is just an enabling factor; the responsibility for success still lies with the people-educators, as well as students-making proper use of it. E-Assessment is an electronic assessment process where technology such as computers or laptops, smartphones, iPads, or electronic gaming devices, can be used to present assessment activities and save responses or answers [20].

MySQL is one type of database server that is very well known. Its popularity is due to MySQL using SQL as the basic language to access its database. MySQL including type RDBMS (Relational Database Management System). In MySQL, a database contains one or a number of tables. The table consists of several rows, and each row contains one or several columns [21]. MySQL is one type of database server that is very well-known and is widely used to build web applications that are databases as sources and data management. MySQL popularity is because MySQL uses SQL as the basic language to access its database, so it is easy to use. MySQL is also open source and frees on various platforms except for Windows that is shareware [22].

In this study, the purpose of this study is to create a mobile-based assessment instrument to see the character of student independence in learning, both at elementary school, junior high school, and senior high school.

\section{Methodology}

This study was carried out by stages, namely Develop, Implementation, and Evaluate. Develop carried out the stage of developing and making e-assessment based on the flowchart and storyboard that already exists. The implementation phase begins with the steps to simulate and apply the E-Assessment character of student learning independence in science subjects to respondents of students and teachers. Evaluation is used as long as to describe the measurements referenced criteria that have high potential to influence the decision-making process in this study using a questionnaire for the instrument [23].

a) The Development Stage: At this stage, the development and manufacture of eassessments based on flowchart and storyboard are carried out. In this stage, the analysis consists of a review of hardware requirements (hardware) and software 
(software). Analysis of hardware requirements (Hardware) is carried out to find out and obtain the tools that need to be fulfilled to run the application to develop an eassessment. The software requirements analysis is done to find out what software needs to be prepared so that an e-assessment can be developed. Software design is a process that consists of four different attributes, namely data structure, software architecture, interface representation, and algorithms. The design process translates requirements into programs developed from [23].

b) Implementation Stage: The implementation phase begins with the steps to simulate and apply the E-Assessment character of student learning independence in science subjects to respondents of students and teachers. The first step is an E-Assessment simulation to small groups, and then a small group is tested to find out how students assess the student's learning independence E-Assessment. Next is conducting E-Assessment research through the MySQL system to respondents of 529 students and 14 teachers. After knowing that e-assessment of student learning independence is feasible to use. The stage of application of E-Assessment character of student learning independence that has been carried out on respondents as many as 529 students and 14 teachers. This stage is a test of large groups.

c) Evaluation Stage: At this stage, a thorough evaluation is carried out. Every process that has been passed to produce a product e-assessment. Evaluation is carried out with a series of empirical tests involving users (students and teachers) of the models that have been developed.

In this study, there is content validity carried out in consultation with experts (Experts Judgment validation criteria) in accordance with their fields. The validity test in this study involved media experts. Content validity can be seen from the suitability of the product with the demands of the curriculum [26]. The assessment criteria are shown in Table 1.

Table 1. Validation criteria

\begin{tabular}{|c|l|}
\hline Interval & \multicolumn{1}{|c|}{ Category } \\
\hline $0.0-25.0$ & Very Inadequate \\
\hline $25.1-50.0$ & Not Feasible \\
\hline $50.1-75.0$ & Worthy \\
\hline $75.1-100.0$ & Very Decent \\
\hline
\end{tabular}

Construct validity, concerning the construct or structure and psychological characteristics of the aspects to be measured by the instrument. Does the construct explain the differences in individual activities or behavior about the aspect being measured? In this study, 529 samples consisting of 170 elementary school students, 175 junior high school students, and 184 senior high school students in Jambi were selected using a purposive sampling technique. Purposive sampling is to choose samples based on certain criteria [27]. In this case, the school criteria used are nationally accredited A. Data collection procedures for referring [26], are explained in the figure below: 


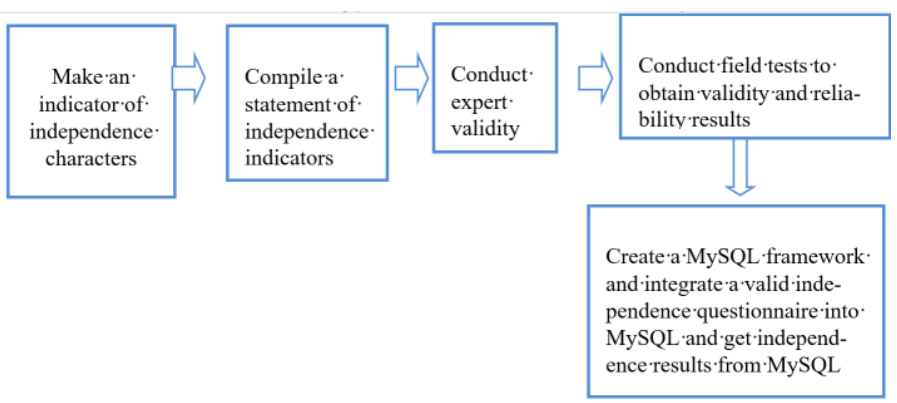

Fig. 1. Data Collection

The categories in this study itself can be seen in the following table 2 .

Table 2. Category of Independence Characters and Teacher Responses

\begin{tabular}{|c|c|l|}
\hline \multicolumn{2}{|c|}{ Interval } & \multirow{2}{*}{ Category } \\
\hline Independence Characters & Teachers Responses & \\
\hline $24.0-43.2$ & $15.0-27.0$ & Very Not Good \\
\hline $43.3-62.5$ & $27.1-39.0$ & Not Good \\
\hline $62.6-81.8$ & $39.1-51.0$ & Enough \\
\hline $81.9-101.1$ & $51.1-63.0$ & Good \\
\hline $101.2-120.0$ & $63.1-75.0$ & Very Good \\
\hline
\end{tabular}

\section{$3 \quad$ Results}

In terms of student characteristics, namely student learning independence, independence learning is an effort made by individuals to carry out learning activities by not relying continuously on other people both in thinking and acting. Self-regulated learning is both a theory and a field of research on self-regulated school learning which emerged in the mid-1980s [24]. Focusing on the principle that learning is an active and constructive process, research has inquired into how learners can take control of their learning processes [25]. Vocational learning is reviewed from eassessment and evaluation, which is used to measure student learning independence. The development of online assessment or can be called e-assessment is an effort to replace conventional assessment into computer-based assessment [26]. [27] in online learning and assessment (e-assessment) there are several advantages, namely learning in learning so that it is more refreshing (fresh), skills in managing more content. Therefore an online assessment or e-assessment is needed. E-assessment using MySQL software. [28] said, the MySQL database management system is used for storing the data, whereas the functionality and user interface are provided by serverside PHP scripts. The advantages of MySQL are: MySQL is a multi-threaded program, so it can be installed on multi-CPU servers; Supported general programs such as C, C ++, Java, Perl, PHP, Python, TCL APIs; Works on various platforms; Has a 
lot of column types, making it easier for database system configurations; Has a fairly good security system with host verification; Supports ODBC for Microsoft Windows operating systems; Supports records that have columns of fixed length or varying lengths; MySQL is free software, and can be downloaded at www.mysql.com while other database software such as ORACLE is software that must be purchased [29]. MySQL was originally developed to handle large databases much faster than existing solutions and has been successfully used in highly demanding production environments for several years. Its connectivity, speed, and security make the MySQL server highly suited for accessing databases on the Internet [30].

\subsection{Expert validation}

Based on the results of the validation done by media experts, it was found that the Independence characters assessment was very good and feasible to be used as an assessment in measuring student character in learning, and greatly facilitated teachers and students in assessing themselves without having to use guidelines based on paper (see Table 2).

Table 3. Results from expert validation of e-independence characters assessments

\begin{tabular}{|c|l|c|c|}
\hline No & \multicolumn{1}{|c|}{ Aspect } & Feasibility Level & Category \\
\hline 1 & Theory & 87.3 & \multirow{2}{*}{ Very Decent } \\
\hline 2 & Display & 89.6 & \\
\hline 3 & Language & 88.5 & \\
\hline
\end{tabular}

From the validation done by the experts, it was found that the very feasible category for the material aspect with a level of eligibility was 87.3 , the display aspect was 89.6 with a very feasible category, and the language aspect had a feasibility level of 88.5 , which meant it was very feasible. Therefore, based on the results of the validation done by the expert, it can be concluded that the e-independence character assessment used to measure student interest is very feasible and good to use.

\subsection{Learning independence}

The results of the student learning independence questionnaire can be seen in the following Table 3: 
Table 4. Results of Questionnaire for Learning Independence of Students at Jambi School

\begin{tabular}{|c|c|c|c|c|c|c|}
\hline \multicolumn{3}{|c|}{ Category } & \multirow{2}{*}{ Mean } & \multirow{2}{*}{ Min } & \multirow{2}{*}{ Max } & \multirow{2}{*}{$\%$} \\
\hline Interval & Attitude & Total & & & & \\
\hline $24.0-43.2$ & Very Not Good & 0 & \multirow{5}{*}{91.4} & \multirow{5}{*}{51} & \multirow{5}{*}{120} & 0 \\
\hline $43.3-62.5$ & Not Good & 3 & & & & 0.6 \\
\hline $62.6-81.8$ & Enough & 85 & & & & 16.1 \\
\hline $81.9-101.1$ & Good & 348 & & & & 65.8 \\
\hline $101.2-120.0$ & Very Good & 93 & & & & 17.6 \\
\hline TOTAL & & 529 & & & & 100 \\
\hline
\end{tabular}

In Table 3, the results of the student learning independence questionnaire were obtained with the number of 529 respondents from the first secondary school that had been processed using the SPSS program, with the following results: Standard Deviation 10.5, Mean 91.41, Mode 92, Median 92, Score Minimum 51, and Score Maximum 120. Data is processed using the SPSS application. The results showed that students' attitudes were in the good category with a percentage of $65.8 \%$ (for a total of 348 out of 529 students), a very good category with a percentage of $17.96 \%$ (for a total of 93 out of 529 students), a sufficient category with a percentage of $16.1 \%$ (for a total of 85 of 529 students). Attitude result data is in the bad category with a percentage of $0.6 \%$ for a total of 3 out of 529 students, and for the very poor category, it has a percentage of $0 \%$ for a total of 0 out of 529 students.

Independence of learning is a necessity and demand in education today. The level of student learning independence can be determined based on how much the initiative and responsibility of students play an active role in terms of learning planning, learning processes, and evaluation of learning. The higher the active role of students in various activities indicates that these students have a high level of learning independence [31]. [32] states that learning independence is an active learning activity, which is driven by the intention or motive to master a competency to overcome a problem, and is built up with the knowledge or competence possessed. Determination of competencies as learning objectives, and ways of achieving them both learning time, place of study, the rhythm of learning, the tempo of learning, learning methods, and evaluation of learning - are carried out by students themselves.

\subsection{Teacher response}

The results of the teacher response questionnaire can be seen in the following table 2: 
Table 5. Results of Student Learning Resources Questionnaire at the Jambi School

\begin{tabular}{|c|c|c|c|c|c|c|}
\hline \multicolumn{3}{|c|}{ Category } & \multirow{2}{*}{ Mean } & \multirow{2}{*}{ Min } & \multirow{2}{*}{$\operatorname{Max}$} & \multirow{2}{*}{$\%$} \\
\hline Interval & \begin{tabular}{|l|} 
Attitude \\
\end{tabular} & Total & & & & \\
\hline $15.0-27.0$ & $\begin{array}{l}\text { Very Not } \\
\text { Good }\end{array}$ & 0 & \multirow{5}{*}{62.1} & \multirow{5}{*}{56} & \multirow{5}{*}{70} & 0 \\
\hline $27.1-39.0$ & Not Good & 0 & & & & 0 \\
\hline $39.1-51.0$ & Enough & 0 & & & & 0 \\
\hline $51.1-63.0$ & Good & 8 & & & & 57 \\
\hline $63.1-75.0$ & Very Good & 6 & & & & 43 \\
\hline TOTAL & & 14 & & & & 100 \\
\hline
\end{tabular}

In table 2, the results of the teacher's questionnaire responses to student learning independence were obtained with the number of 14 respondents from the first secondary school that had been processed using the SPSS program, with the following results: Mean 62.2, Mode 56, Score Minimum 56, and Score Maximum 70. The data is processed using the SPSS application, while the data on attitudinal results have a good category of $57 \%$ for a total of 8 out of 14 teachers. Data on attitudinal results have a Very Good category of $43 \%$ for a total of 6 of 14 teachers. Data on attitudinal results have a sufficient category of $0 \%$ for a total of 0 out of 14 teachers. Data on attitudinal results have a category of Not Good at $0 \%$ for a total of 0 out of 14 teachers, and data on attitudinal results have a very bad category of $0 \%$ for a total of 0 out of 14 teachers.

The program system developed is an e-assessment that uses program language that is made on Macromedia Dreamweaver MX 2004 applications in the form of PHP. Using PHP uses a scripting language that embeds HTML from web pages. When the evaluator wants to return to the destination, the webserver executes the PHP script and replaces the results back to the page [33]. The use of e-assessment applications is used for e-assessment and evaluation of student learning independence.

The work system in e-assessment and evaluation is: on the start page, there are three main menus, namely the homepage menus. The homepage menu contains images of researchers while observing a junior high school in Muaro Jambi. The Science menu contains three menus, namely the home menu to return to the start menu, the learning independence menu, which contains student learning independence questionnaires in science subjects, and the science attitude menu, which contains student science attitude questionnaires. After the data is inputted by students or teachers on each questionnaire, then the data will be stored automatically on the database contained in MySQL. We can display data on MySQL in ordinary data and in graphical form like Figure 5.

The core of the assessment activity is to determine the value of an object by comparing it with certain criteria. Basically, assessment can be helped by the development of technology and information [34]. Recognizes that self-regulation applies not just to cognition but also to motivational beliefs and overt behavior [35]. It also recognizes that there are limits to learner self-regulation; for example, the teacher usually devises the learning task and determines the assessment requirements. Eassessment and evaluation of learning independence can be seen initially in Figures 2: 


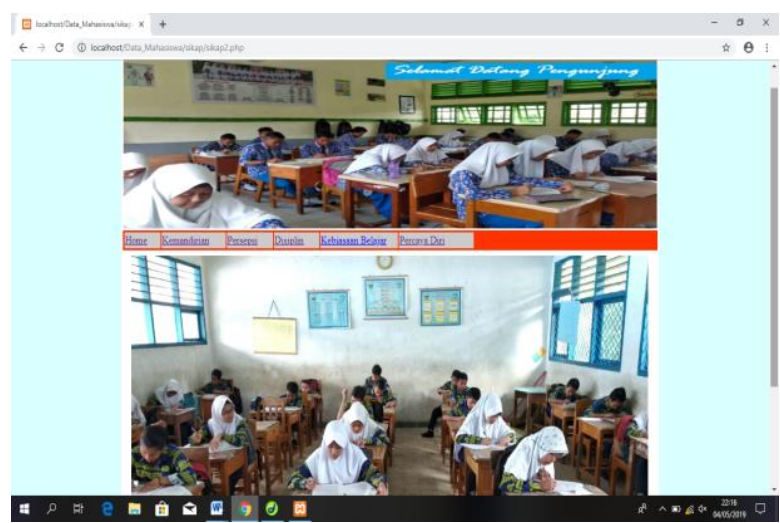

Fig. 2. The initial appearance of the e-assessment and evaluation of student learning independence

Figure 2 shows the homepage of the learning independence e-assessment of students in the MySQL program.

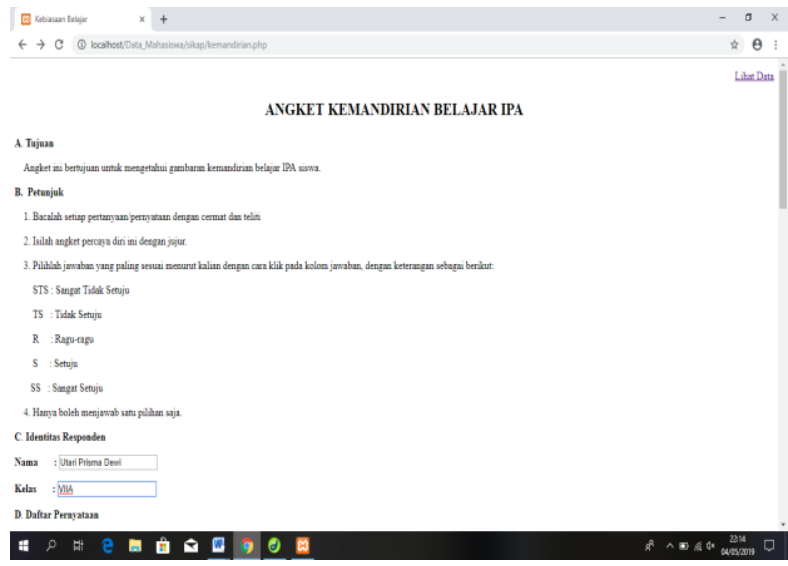

Fig. 3. Display of Biodata E-Assessment and Evaluation of Learning Independence

Figure 3 shows the biodata of the motivation e-assessment of students in the MySQL program. 


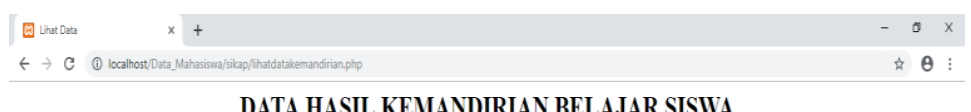

DATA HASIL KEMANDIRIAN BELAJAR SISWA

$\underline{\text { Masilian Data Baru Gafait }}$

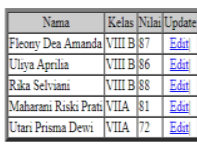

Fig. 4. Display of Results from E-Assessment and Evaluation of Learning Independence

Figure 4 shows the results of the e-assessment and evaluation of student learning independence from students who have filled out the student learning independence questionnaire in the MySQL program.

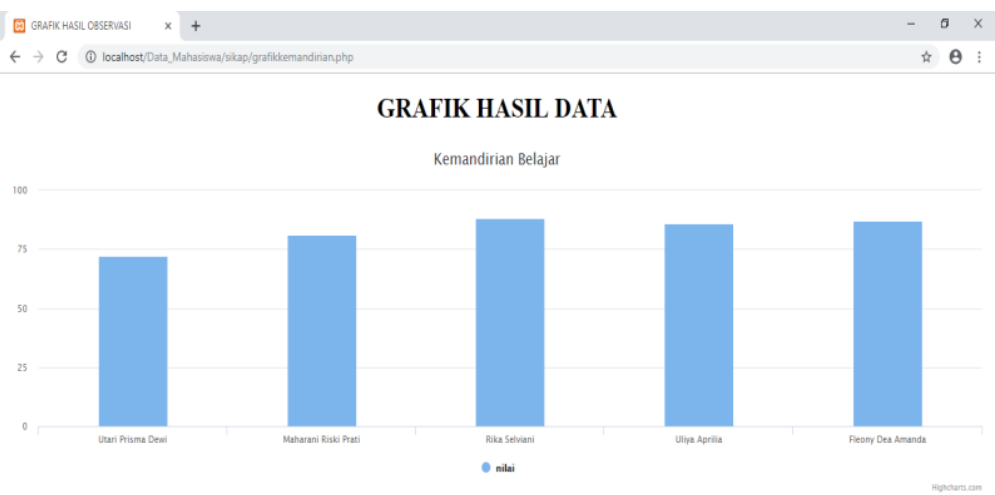

* $\rho$ 붕

Fig. 5. Graph of results from E-Assessment and Evaluation of Learning Independence

Figure 4. A graph of the results of e-assessment and evaluation of learning independence of students who have filled out the student learning independence questionnaire in the MySQL program. 


\section{Discussion}

Educational technology is the study and ethics of training to facilitate learning and enhance learning by creating, using, and managing appropriate technological processes and resources [36]. [37] states, rapid changes in the present are mainly due to technological advances. Technology can be considered as a catalyst for change, which is to make change revolutionary, very fast, and intensive. In the world of education and knowledge, this revolution is ongoing and has a double dimension, which connects amazing modern brain research with the power of information and knowledge that can be accessed quickly and easily through information and communication technology (Information and Communication Technology, ICT). In this case, the reform in the form of e-assessment and evaluation that uses ICT in learning that can provide convenience and benefits to users, namely (students and teachers). E-Assessment can be divided into different types according to the main purpose of the assessment (though these types also apply to conventional assessments): (1) Diagnostic assessment, normally at (or even before) the beginning of the teaching program, for placement or streaming purposes, or to identify necessary remedial work. e-Assessment's instant marking can be of great benefit here. (2) Formative assessment allows students and their teachers to gauge how much has been learned, identify areas where further work is necessary, and help students to reinforce their learning. e-Assessment allows students to receive feedback while they are still focussed on the subject. (3) Summative assessment, has as its aim the measurement of student learning, usually at the end of a program of study. Success is normally the prerequisite for award of grades, degrees, or progression to further study. Feedback, other than a mark or grade, is not normally provided [38].

[39] said the advantages of e-assessment include four main things, namely efficiency, effectiveness, authenticity, and involvement. Strengths in terms of efficiency include: (1) scheduled implementation, meaning when the assessment is carried out and when the e-assessment is terminated can be arranged according to the wishes of the teacher, (2) reports, meaning that when the assessment has completed the results of the assessment can be reported directly to anyone with interest in the assessment, for example, schools, parents, or others, (3) automatic responses, meaning that when students complete the e-assessment, it will automatically get an answer or response from the system, (4) storage of results and values, meaning E-Assessment has the ability to conduct feedback on results and values. Strengths in terms of effectiveness include (1) immediate feedback, meaning that when using E-Assessment students can immediately get feedback on the results of the assessment conducted, whether the student has met the assessment standards or not, (2) analysis of question validity, meaning that the E-Assessment can be a tool to be able to analyze the validity of the questions given, (3) the type of new questions, meaning that many types of questions can be used according to the teacher's needs for assessment.

Strengths in terms of authenticity include (1) access to people and resources, meaning that anyone who uses the source of assessment from E-Assessment can be known authenticity so that it will not cause misjudgment because of wrong people, (2) can be designed according to situations in the real world, meaning that even though the as- 
sessment is done electronically, the implementation can be designed so that it looks like a situation in the real world, (3) can arrange complex tasks, meaning that the EAssessment allows the teacher to want to provide complex tasks to students. Strengths in terms of involvement include: (1) can use cyberspace, meaning that assessment can be done through cyberspace, (2) can be used to review yourself or friends, meaning through E-Assessment allows students to be able to correct the results of their own work, besides the work can also be corrected by peers.

Evaluation is carried out with empirical tests involving users, namely (students and teachers) of the models that have been developed. The results of the questionnaire teacher responses to student learning independence have been processed using the SPSS program application, with the following results: Standard Deviation 10.5, Mean 91.41, Mode 92, Median 92, Score Minimum 51, and Score Maximum 120. The data is processed using the SPSS application, while the data on attitudinal results have a good category of $65.8 \%$ for a total of 348 of 529 students. Data on attitudinal results have a Very Good category of $17.96 \%$ for a total of 93 out of 529 students. Data on attitudinal results have a sufficient category of $16.1 \%$ for a total of 85 out of 529 students. Data on attitudinal results have a Not Good category of $0.6 \%$ for a total of 3 out of 529 students, and the data on attitude attitudes have a very bad category of $0 \%$ for a total of 0 out of 529 students. The results of the teacher's questionnaire responses to students' learning independence with the number of 14 respondents from the first, middle school who have been processed using the SPSS program, with the following results: Standard Deviation 4.97, Mean 62.14, Mode 56, Median 62, Score Minimum 56, and Score Maximum 70. The data is processed using the SPSS application, while the data on attitudinal results have a good category of $50 \%$ for a total of 7 out of 14 teachers. Data on attitudinal results have a Very Good category of $50 \%$ for a total of 7 of 14 teachers. Data on attitudinal results show $0 \%$ for sufficient category, not a good category, and a very bad category for a total of 0 out of 14 teachers.

Based on the results of the data, it is said that students have an interest in learning science subjects so that students have learning independence. The independence of student learning can be seen in the indicators of motivation and good assignment due to the strong encouragement of students when working on the assignments of science subjects given by the teacher. In line with [40]; [41]; [42] students who have high learning independence will try to complete all the exercises or assignments given by the teacher with their own abilities. If students get into trouble, then the student will ask questions or discuss with friends, teachers, or other parties who are more competent in overcoming these difficulties. Furthermore, the independence of learning in schools is seen when students can express their opinions spontaneously when discussing in class and answering questions given by the teacher. This is in line with [43]; [44]; [45] which states the activity of students can be seen in their daily activities, for example, he often reads textbooks, seriously listens to teacher's information, often asks the teacher, is active in class discussions, diligently practices in mastering skills and others. The general assumption of most of the models of self-regulated learning is that self-regulatory activities are mediators between personal and contextual characteristics and actual achievement or performance [46]; [47]; [48]. 


\section{Conclusion}

The results of the system description, e-assessment of learning independence are made with MySQL software, because of the ease of installation and use and small hard drive and memory traces. And this application can use multi-threaded so that the directing process of several students can be used simultaneously. The instrument of independence characters has been tested by experts in their fields and obtained valid statements of 24 statements with a reliability value of 0.870 . Exploration results show that affective assessment uses e-assessment and evaluation of learning independence of students who have a good category of $65.8 \%$, with a total of 348 students from 529 students. Then the response of teachers using e-assessment and independent learning evaluation is in the very good and good category $50.0 \%$ with a total of 7 teachers from 14 teachers, which means the teacher's response to student learning independence in e-assessment and evaluation is very good in evaluation. It can be stated that e-assessment is important to use because it can facilitate the teacher or student in conducting an assessment and evaluation on him.

\section{References}

[1] Astalini, D. A. Kurniawan, Darmaji., L. R. Sitorus, R, Perdana, R. "Characteristic Of Students Attitude To Physics In Muaro Jambi High School." Humanities \& Social Science Reviews. Vol, 7, no. 2, pp. 91-99. 2019. https://doi.org/10.18510/hssr.2019.7210

[2] D. A. Kurniawan, Astalini., \& L. Anggraini. "Evaluation of SMP Attitudes Towards Natural Sciences in Muaro Jambi Regency." Jurnal Ilmiah Didaktika: Media Ilmiah Pendidikan dan Pengajaran, vol. 19, no. 1, pp. 123-139. 2018. https://doi.org/10.22373/ jid.v12i2.457

[3] Astalini, D. A. Kurniawan, R. Perdana, D. Kurniasari, "Identification of Student Attitudes toward Physics Learning at Batanghari District High School.” The Educational Review, USA, vol. 2, no 9, pp. 475-484. 2018. https://doi.org/10.26855/er.2018.09.003

[4] Astalini, D. A.Kurniawan, R. Perdana, \& W. Kurniawan, "Identification Attitudes of Learners on Physics Subject." EST Journal of Educational Science and Technology. Vol. 5, no. 1, pp. 39-48. 2019. https://doi.org/10.26858/est.v5i1.8231

[5] Regulation of the Minister of National Education. Number 20 of 2003

[6] S. Zubaidah, "21st Century Skills: Skills taught through learning." In the National Education Seminar with the theme "MIPA Century Strategic Learning Issues, vol. 21, no. 10. 2016.

[7] E. Y. Wijaya, D. A. Sudjimat, A. Nyoto, \& U. N. Malang, "Transforming 21st century education as a demand for human resource development in the global era." In Prosiding Seminar Nasional Pendidikan Matematika, vol. 1, no. 26, pp. 263-278. 2016.

[8] Oliver, R.. The role of ICT in higher education for the 21 st century: ICT as a change agent for education. Retrieved April, 14, 2002.

[9] JISC. (2016). Introduction to e-learning. Retrieved from https://www.webarchieve.org.uk/ wayback/archieve/20160101151755 http://www.jiscdigitalmedia.ac.uk/guide/introduction-to-elearning. 
[10] Tessier, D., \& Dalkir, K. Implementing Moodle for e-learning for a successful knowledge management strategy. Knowledge Management \& E-Learning, 8(3), 414. 2016. https://doi.org/10.34105/j.kmel.2016.08.026

[11] Olasina, G. Factors of best practices of e-learning among undergraduate students. Knowledge Management \& E-Learning: An International Journal, 10(3), 265-289. 2018 https://doi.org/10.34105/j.kmel.2018.10.016

[12] Buzzetto-More, N. A., \& Alade, A. J. Best practices in e-assessment. Journal of Information Technology Education: Research, 5(1), 251-269. 2006. https://doi.org/10.28945 $\underline{1246}$

[13] Sumarmo, U. Independence of learning: what, why, and how it is developed in students. In Paper at the National Level Seminar. FPMIPA UNY Yogyakarta (Vol. 8). 2004.

[14] Salamah, U. Quality Assurance of Educational Assessment. Evaluation, 2(1), 274-293. 2018

[15] Karli, H. Application of Thematic Learning to Develop Science Process Skills in Elementary Schools. Jurnal Pendidikan Penabur, 9(14), 44-57. 2010

[16] Supratiknya, A. Assessment of learning outcomes with non-test techniques. Yogyakarta: Universitas Sanata Dharma. 2012.

[17] Fuller, M. B. An Empirical Study of Cultures of Assessment in Higher Education. NCPEA Education Leadership Review, 14(1), 20-27. 2013.

[18] Anwar, H. Assessment of scientific attitudes in science learning. Jurnal Pelangi Ilmu, 2(5). 2009.

[19] Amelung, M., Krieger, K., \& Rösner, D. E-Assessment as a Service. IEEE Transactions on Learning Technologies, 4(2), 162-174. 2011.

[20] Permadi, T., \& Mustangin, M. Development Of Attitude Of E-Assessment In The Middle School Of Mathematical Learning. JPM: Jurnal Pendidikan Matematika, 1(2), 118-126. 2015. https://doi.org/10.33474/jpm.v1i2.719

[21] Sutopo, P., Cahyadi, D., \& Arifin, Z. Executive Information System for Web-based Distribution of 2-Wheeled Vehicle Sales in East Kalimantan. 2017.

[22] Arief M.Rudyanto, Dynamic Web Programming Using PHP and MySQL. Yogyakarta: 2011.

[23] Ivers, K. S., \& Barron, A. E. Multimedia Project in Education: Designing, Producing, and Assessing. USA: Libraries Unlimited. 2002.

[24] Bramucci, Annarita. Self-Regulated Learning: Theories and Potential Applications and Didactics. Inteligent Tutor: Lifelong Learning. 1-22. 2013.

[25] Maison, Syahrial, Syamsurizal, and Tanti, "Learning environment, students' beliefs, and self-regulation in learning physics: Structural equation modeling," J. Balt. Sci. Educ., vol. 18, no. 3, pp. 389-403, Jun. 2019. https://doi.org/10.33225/jbse/19.18.389

[26] Sahidu, H., Gunawan, G., Indriaturrahmi, I., \& Astutik, F. E-Assessment System Design on Physics Learning at LPTK. Jurnal Pendidikan Fisika dan Teknologi, 3(2), 265-270. 2017. https://doi.org/10.29303/jpft.v3i2.422

[27] Garrison, D. R., \& Vaughan, N. D. Blended learning in higher education: Framework, principles, and guidelines. John Wiley \& Sons. 2008.

[28] Korhonen, K., Donadini, F., Riisager, P., \& Pesonen, L. J. GEOMAGIA50: An archeointensity database with PHP and MySQL. Geochemistry, Geophysics, Geosystems, 9(4), 2008 https://doi.org/10.1029/2007gc001893

[29] Pressman, Roger S. Software Engineering. Yogyakarta : Andi and McGraw-Hill Book Co. Page 53 - 56. 2002

[30] Di Giacomo, M. MySQL: lessons learned on a digital library. IEEE Software, 22(3), 1013. 2005. https://doi.org/10.1109/ms.2005.71 
[31] Fahradina, N., \& Ansari, B. I. Mathematical Communication Capability Improvement and Learning Independence of Middle School Students Using Group Investigation Models. Didactic Mathematics Journal, 1(2). 2014.

[32] Kurniawan, Endar. A. The Influence of Learning Independence and Scientific Attitudes in Verification Based Experiments on Physics Science Learning Outcomes of Grade VII Students Even Even in Wonosobo N 2 Middle School 2012/2013 Academic Year Radiation. 4(1). 73-78. 2012.

[33] William, H, E., \& Lane, D. Web Database Application With PHP and MySQL, 2nd Edition. America: O'Reilly. 2009.

[34] Supratiknya, A. Assessment of learning outcomes with non-test techniques. Yogyakarta: Universitas Sanata Dharma. 2012.

[35] Nicol, D. J., \& Macfarlane, D, D. Formative assessment and self-regulated learning: a model and seven principles of good feedback practice. Studies in Higher Education, 31(2), 199-218. 2006 https://doi.org/10.1080/03075070600572090

[36] Nurdyansyah, N. Resources in Educational Technology. Universitas Muhammadiyah Sidoarjo. 2017.

[37] Suryadi, A. Use of ICT in learning. Jurnal Pendidikan Terbuka dan Jarak Jauh, 8(3), 83-96. 2007. https://doi.org/10.33830/ptij.v20i2.2019

[38] Cook, J., \& Jenkins, V. Getting started with e-assessment. University of Bath, Bath. 2010.

[39] Crisp, Geoffrey. Teacher's Handbook on e-Assessment. Australia: Department of Education, Employment, and Australian Government Employment Relations. 2011

[40] Al-Fatihah, M. The Relationship Between Learning Independence and Learning Achievement Pai Class III Students at Elementary School Panularan Surakarta. At-tanbawi. Volume. 1(2), 197-208. 2016

[41] Solichin, M.M. Learning and teaching in view Al-Ghazâlî. Tadrîs, 1(2). 139-153. 2006

[42] Pintrich, P. R. The Role of Goal Orientation in Self-Regulated Learning. In Handbook of Self-Regulation, 451-502. 2000. https://doi.org/10.1016/b978-012109890-2/50043-3

[43] Astalini, A., Kurniawan, D. A., Sulistiyo, U., Perdana, R., \& Susbiyanto, S. E-Assessment Motivation in Physics subjects for Senior High School. International Journal of Online and Biomedical Engineering (iJOE), 15(11), 4-15. 2019. https://doi.org/10.3991/ ijoe.v15i11.10843

[44] Asrial, A., Syahrial, S., Kurniawan, D. A., Subandiyo, M., \& Amalina, N. Exploring obstacles in language learning among prospective primary school teacher. International Journal of Evaluation and Research in Education (IJERE),8(2), 249-254. 2019. https://doi.org/10.11591/ijere.v8i2.16700

[45] Darmaji, D., Kurniawan, D. A., \& Irdianti, I. Physics education students' science process skills. International Journal of Evaluation and Research in Education (IJERE),8(2), 293298. 2019. https://doi.org/10.11591/ijere.v8i2.16401

[46] Tuluk, G., \& Kepeceoglu, I. Pre-service teachers' web pedagogical content knowledge and online information searching strategies. International Journal of Evaluation and Research in Education (IJERE), 8(2), 229-236. 2019. https://doi.org/10.11591/ijere.v8i2. $\underline{18771}$

[47] Semin, F. K. Competencies of principals in ensuring sustainable education: Teachers' views. International Journal of Evaluation and Research in Education (IJERE), 8(2), 201212. 2019. https://doi.org/10.11591/ijere.v8i2.18273

[48] Tentama, F., Subarjo, S., \& Abdillah, M. H. Motivation to learn and social support determine employability among vocational high school students. International Journal of Evaluation and Research in Education (IJERE), 8(2), 237-242. 2019. https://doi.org/10. $\underline{11591 / \text { ijere.v8i2.18188 }}$ 


\section{Authors}

Asrial is a professor in the study of indigenous knowledge chemical field. This knowledge can be applied to 21st Century learning at the elementary, junior and senior high school levels. And preparing teacher candidates to understand the value of local wisdom to improve competence pedagogical. By applying education based on local wisdom it is hoped that it will be able to create education that gives meaning in the learning process for students. So that education is able to create young generations who are able to preserve and love their own culture. In addition, education must be able to shape human character with high integrity and great character and dignity in accordance with the spirit of education which is humanizing humans. Asrial is the chair of the research group ethnoconstructivism and that group is aimed at analyzing all the values of local wisdom to serve as a medium and source of learning.

Syahrial is an associate professor in the study of indigenous knowledge language and linguistic field. Language as a cultural product of local wisdom is one of the markers of civilization. Ethnic language (local) has an important function and role as important as the national language and international language as a bridge in global communication. Decreasing the vitality of ancestral languages will affect the safeguarding of local wisdom values. Noble advice contained in culture will stop being inherited as language skills fade. So from that, the value of local wisdom must be maintained, explored and developed for students. This is intended so that later the development of culture and science becomes the basis for human resource development. Syahrial is a member of the research group ethnoconstructivism and works at the Elementary Teaching and Education Program, Universitas Jambi. Email: Syahrial.karea@gmail.com

Maison is an associate professor in the field of physics education in the field of physics (science) curriculum, misconceptions and characters. This research is useful to map students' abilities in terms of character, an attitude so thatit can be given a curriculum evaluation and new curriculum innovations in terms of character and attitude enhancement.

Muhaimin is an associate professor at Department of Chemistry Education, Faculty of Education, University of Jambi, Jambi, Indonesia. He has experience in the area of Organic Chemistry, Pharmaceutical Technology, and Pharmacognosy, working in drug delivery, drugs discovery of herbal plants, antimalaria and infectious disease. His research also focus on polymer and organic chemistry from mechanistic studies to synthetic methodology and the synthesis of natural products as well as of structurally intriguing heterocyclic compounds. The central focus of the research is the design of new methods for the synthesis of bioactive and synthetically versatile compounds. Other his research focus on innovative drug delivery systems with controlled drug release.

Dwi Agus Kurniawan is a lecturer and member of the ASPS Group Research (Attitude Towards Science and Science Processing Skills). His research interest includes E-Assessment and Evaluation specially in Attitude towards Physics and Science Processing Skills. The age level of a child will experience very much difference, both in the form of his mindset, his skills, his relationships, and his attitude as a student. For 
teachers, it is very useful to know the differences in the mindset of their students, and about their daily interactions, and the behavior of their students. Benefits that can be obtained are: can create the right classroom for students, can provide innovative and varied learning methods, can provide lessons on deep moral aqidah, and explain the consequences for those who violate certain rules. He works at Science Education Program, Jambi University Indonesia.

Article submitted 2020-01-02. Resubmitted 2020-05-25. Final acceptance 2020-05-27. Final version published as submitted by the authors. 